\title{
Relationship of the Environmental Condition with the Presence of Leptospira in Rats in Flood Prone Areas in Makassar City
}

Muhammad Rifaldi Anwar ${ }^{1}$, Syamsuar Manyullei ${ }^{1 *}$, Rizalinda Sjahril ${ }^{2}$, Anwar Daud ${ }^{1}$, Anwar Mallongi ${ }^{1}$, Healthy Hidayanty $^{3}$

${ }^{1}$ Department of Environmental Health, Faculty of Public Health, Hasanuddin University, Indonesia

${ }^{2}$ Department of Microbiology, Faculty of Medicine, Hasanuddin University, Indonesia

${ }^{3}$ Department of Nutrition, Faculty of Public Health, Hasanuddin University, Indonesia

DOI: $10.36348 /$ sjnhc.2020.v03i08.001

| Received: 05.07.2020 | Accepted: 25.07.2020 | Published: 03.08.2020

*Corresponding author: Syamsuar Manyullei

\section{Abstract}

Cases of leptospirosis in Indonesia increased dramatically in 2018 by 895 cases with 148 death cases due to leptospirosis in 2018. Risk factors were found in more than half of leptospirosis events including environmental conditions, the presence of rodents, waste water disposal, waste disposal facilities, history of contact with rats, presence of rivers, and history of flooding. Previous research has reported the finding of mice containing Leptospira in post-flood areas in Indonesia. Therefore this study aimed to determine the relationship of environmental conditions with the presence of Leptospira bacteria in rats in flood-prone areas. This research is an analytic study with cross sectional approach. Data obtained by observing the type of rat, the process of surgery and taking rats, rats calculation of success traps_and observation of environmental conditions. The polymerase chain reaction (PCR) test was carried out in the Microbiology Laboratory of Hasanuddin University Hospital. Statistical tests with fisher exact were used to determine the relationship of environmental conditions with the presence of Leptospira bacteria in rats. The results of this study found $100 \%$ Mus musculus, 53.3\% Rattus norvegicus, 22.2\% Rattus tanezumi infected with Leptospira bacteria. The results showed the presence of sewers with stagnant water $(0,000)$, presence of standing water other than sewers $(0,026)$, presence of sewage waste $(0,005)$, presence of waste other than ditches $(0,007)$, smell of rat urine $(0,049)$ and $\mathrm{pH}$ of stagnant water the optimum (0.001) with a p-value $<0,05$. We recommend to the Paccerakkang inhabitants who reside in flood-prone areas, to always maintain environmental conditions such as cleaning the environment suspected of being a habitat for rats.

Keywords: Rat, Flood prone area, Environment, Leptospira bacteria.

Copyright @ 2020: This is an open-access article distributed under the terms of the Creative Commons Attribution license which permits unrestricted use, distribution, and reproduction in any medium for non-commercial use (NonCommercial, or CC-BY-NC) provided the original author and source are credited.

\section{INTRODUCTION}

Rats can be a reservoir of several pathogens that cause disease in humans. Types of diseases carried by rat include; leptospirosis, pes, typhus, salmonellosis, chagas disease, Q-fever and also some worm diseases such as schistosomiasis and angiostrongyliasi, but the disease that occurs due to rat urine is leptospirosis [1, $2]$.

Many mammal species act as reservoirs of leptospirosis but rats are the main reservoir. There are three types of mice that are widespread in the world and are associated with transmission of leptospirosis, namely Rattus norvegicus, Mus musculus and Rattus tanezumi [3]. Leptospira bacteria were first isolated from the kidneys and urine of black rats (Rattu-rattus) $[4,5]$. In the rat's kidney, the Leptospira bacteria will settle as a chronic infection and can survive as long as the rat lives without causing illness [6].

The environment contaminated with rat urine infected with Leptospira bacteria is the central point of transmission of leptospirosis. During storms or heavy rain, animal urine on the ground or on other surfaces can flow in flood water, river flows, stagnant water and other natural water sources can also be contaminated [6].

Leptospirosis is a disease that is affected by high humidity and warm temperatures allowing the Leptospira bacteria to survive for a long time in the environment. Heavy rain and flooding also increase the incidence of leptospirosis. In urban areas, it is driven by factors such as poverty and population density especially in urban slums which are increasingly 
densely populated and inadequate sanitation infrastructure [7].

In 2018 in Indonesia there were seven provinces that reported cases of leptospirosis, namely Jakarta, West Java, Central Java, Yogyakarta, East Java, Banten and Maluku. Cases of leptospirosis increased dramatically in 2018 by 895 cases. There were five provinces that experienced an increase in leptospirosis cases, namely: Jakarta, Central Java, Yogyakarta and Banten. From 2009 to 2018 there were fluctuations in the number of leptospirosis cases. The highest number of cases occurred in 2011 and then decreased until 2015, then increased in 2018. Meanwhile, the number of deaths due to leptospirosis in 2018 with a total of 148 deaths $[8]$.

The South Sulawesi region has a high risk of disease contamination due to rat contamination, which occurs in the Wajo area in the villages of Wiringpalannae and Mattirotappareng. This is seen from the environmental aspect. The intended environmental health risks include the use of surface water sources, namely rivers, distance of water sources and physical quality of water that does not meet health requirements, the absence of sewerage, and the absence of household waste bins. Opportunities for exposure to environmental health hazards are the habit of not washing hands with soap [9].

Research conducted by Sholichah dan Rahmawati [10] regarding the distribution of pathogenic Leptospira infections in rats and shivers in the post-flood areas of Pati Regency and Boyolali endemics, found 7 samples of rats positive Leptospira in Pati, Bakaran Kulon villages, 2 samples of rats positive Leptospira in Sindon village Boyolali and 27 samples of rats positive Leptospira in Jeron Boyolali village used polymerase chain reaction (PCR) examination. Genetic variation of Leptospira isolated from mice captured in Yogyakarta Indonesia, there were 99 mice studied with DNA samples obtained from rat kidney tissue. Leptospira detection using PCR showed positive in 25 samples. There were 6 samples that were confirmed as pathogenic Leptospira by using standard PCR [11].

Risk factors found in more than half of leptospirosis events include environmental conditions, the presence of rodents, waste water disposal, waste disposal facilities, history of contact with mice, use of personal protective equipment, presence of pets at risk, the presence of rivers, and history of flooding 12 . The discovery of positive rats containing Leptospira bacteria in post-flood areas in Indonesia, then the researcher wants to analyze the environmental relationship with Leptospira bacteria in rats in flood prone areas of Makassar City.

\section{METHODS}

Research design

This research was conducted in flood-prone areas in Paccerakkang Sub-district, Biringkanaya District, Makassar City, South Sulawesi. From February to April 2020. The type of research used was analytic research with cross sectional design.

\section{Population and Sample}

The population in this study were all stagnant water and rats in Paccerakkang Village, Biringkanaya District, Makassar City. The number of rat samples as many as 25 heads (Accidental Sampling) in flood-prone areas of Paccerakkang Village, Biringkanaya District, Makassar City.

\section{Data collection}

Data collection methods used in this study were identification of rat species, the process of surgery and rat kidney extraction carried out in the Makassar Port Health Office Vector Laboratory and through polymerase chain reaction (PCR) tests on rat samples conducted at the Microbiology Laboratory of Hasanuddin University Hospital,success trap calculation, and observation of environmental conditions.

\section{Data analysis}

Analysis of the data used in this study is univariate analysis used to find out the description of the characteristics of research subjects, expressed in tables and narratives to find out the proportions of each variable and bivariate analysis to determine the relationship of two variables using the chi square test based on the $2 \times 2$ table at a confidence level of 0.05 and a confidence interval of $95 \%(\alpha=0.05)$. If the value of the chi square crosstabulation has a frequency value that is expected to be less than five, then the fisher exact test is used.

\section{RESULT}

\section{The type of rats that is caught}

Table-1: Types of Rats Caught by Gender in the Flood Prone Areas of Makassar City

\begin{tabular}{|c|c|c|c|}
\hline \multirow{2}{*}{ Type of Rats } & \multicolumn{2}{|c|}{ Gender } & \multirow{2}{*}{ Total (\%) } \\
\cline { 2 - 3 } & Male (\%) & Female (\%) & \\
\hline Rattus norvegicus & $12(80 \%)$ & $3(20 \%)$ & $15(100 \%)$ \\
\hline Rattus tanezumi & $5(55,5 \%)$ & $4(44,5 \%)$ & $9(100 \%)$ \\
\hline Mus musculus & $1(100 \%)$ & $0(0 \%)$ & $1(100 \%)$ \\
\hline
\end{tabular}


Rats caught according to sex in the flood-prone areas of Makassar City, the most commonly found are Mus musculus with $100 \%$ male sex and $44.5 \%$ female Rattus tanezumi. The majority of mice that were caught according to the location of the traps were Mus musculus which were generally caught outside the house by $100 \%$, Rattus tanezumi was caught outside the house by $66.7 \%$, inside the house by $33.3 \%$, while Rattus norvegicus by $60 \%$ which caught outside the home and caught inside the house as much as $40 \%$.

\section{The success of catching (Success Trap) of rats}

Table-2: Types of Rats Caught by Trap Location In the Flood Prone Areas of Makassar City

\begin{tabular}{|c|c|c|c|}
\hline \multirow{2}{*}{ Type of Rats } & \multicolumn{2}{|c|}{ Trap Location } & \multirow{2}{*}{ Total (\%) } \\
\cline { 2 - 3 } & Outdoor (\%) & Indoor (\%) & \\
\hline Rattus norvegicus & $9(60 \%)$ & $6(40 \%)$ & $15(100 \%)$ \\
\hline Rattus tanezumi & $6(66,7 \%)$ & $3(33,3 \%)$ & $9(100 \%)$ \\
\hline Mus musculus & $0(0 \%)$ & $1(100 \%)$ & $1(100 \%)$ \\
\hline
\end{tabular}

The success of catching mice for 4 days in floodprone areas of Makassar City. Can be seen from the number of rats caught using 100 traps (single live trap).

The number of rats caught in the flood-prone area of Makassar City, namely Paccerakkang Village, is 25 rats with a success rate of $25 \%$.

\section{The presence of Leptospira bacteria in rats}

Table-3: Existence of Leptospira Bacteria in Rats in Makassar City Flood Prone Areas
\begin{tabular}{|l|c|c|c|}
\hline \multicolumn{1}{|c|}{ Type of Rats } & Positive Leptospira (\%) & Negative Leptospira (\%) & Total (\%) \\
\hline Rattus norvegicus & $8(53,3 \%)$ & $7(46,7 \%)$ & $15(100 \%)$ \\
\hline Rattus tanezumi & $2(22,2 \%)$ & $7(77,8 \%)$ & $9(100 \%)$ \\
\hline Mus musculus & $1(100 \%)$ & $0(0 \%)$ & $1(100 \%)$ \\
\hline
\end{tabular}

The presence of Leptospira bacteria in rats in the flood-prone areas of Makassar City with the results of the Polymerase Chain Reaction (PCR) showed that from 25 rat samples examined $100 \%$ of Mus musculus kidney samples were positive containing Leptospira

bacteria. Positive Rattus norvegicus kidney samples containing Leptospira bacteria as much as $53.3 \%$ and positive Rattus tanezumi kidney samples containing Leptospira bacteria as much as $22.2 \%$.

\section{The relationship of environmental conditions that affect the presence of Leptospira bacteria in rats}

Table-4: Relationship of Environmental Conditions that Affect the Existence of Leptospira Bacteria in Rats in Flood Prone Areas in Makassar City

\begin{tabular}{|c|c|c|c|c|c|}
\hline \multirow{4}{*}{$\begin{array}{l}\text { The existence of gutters } \\
\text { with stagnant water }\end{array}$} & & \multicolumn{2}{|c|}{ Leptospira Bacteria in Rats } & \multirow[t]{2}{*}{ Total $(\%)$} & \multirow[t]{2}{*}{$p$} \\
\hline & & Positive (\%) & Negative (\%) & & \\
\hline & Yes & $9(100 \%)$ & 0 & $9(100 \%)$ & \multirow[t]{2}{*}{0,000} \\
\hline & No & $2(12,5 \%)$ & $14(87,5 \%)$ & $16(100 \%)$ & \\
\hline \multirow{2}{*}{$\begin{array}{l}\text { The existence of standing } \\
\text { water other than sewers }\end{array}$} & Yes & $4(100 \%)$ & 0 & $4(100 \%)$ & \multirow[t]{2}{*}{0,026} \\
\hline & No & $7(33,3 \%)$ & $14(66,7 \%)$ & $21(100 \%)$ & \\
\hline \multirow{2}{*}{$\begin{array}{l}\text { The existence of garbage in } \\
\text { the gutter }\end{array}$} & Yes & $8(80 \%)$ & $2(20 \%)$ & $10(100 \%)$ & \multirow[t]{2}{*}{0,005} \\
\hline & No & $3(20 \%)$ & $12(80 \%)$ & $15(100 \%)$ & \\
\hline \multirow{2}{*}{$\begin{array}{l}\text { The existence of garbage } \\
\text { other than in the gutter }\end{array}$} & Yes & $7(87,5 \%)$ & $1(12,5 \%)$ & $8(100 \%)$ & \multirow[t]{2}{*}{0,007} \\
\hline & No & $4(23,6 \%)$ & $13(76,4 \%)$ & $17(100 \%)$ & \\
\hline \multirow{2}{*}{$\begin{array}{l}\text { The availability of } \\
\text { affordable food for rats }\end{array}$} & Yes & $4(50 \%)$ & $4(50 \%)$ & $8(100 \%)$ & \multirow[t]{2}{*}{1,000} \\
\hline & No & $7(41,1 \%)$ & $10(58,9 \%)$ & $17(100 \%)$ & \\
\hline \multirow{2}{*}{$\begin{array}{l}\text { The conditions of the } \\
\text { garbage shelter }\end{array}$} & Open & $9(60 \%)$ & $6(40 \%)$ & $15(100 \%)$ & \multirow[t]{2}{*}{0,099} \\
\hline & Closed & $2(20 \%)$ & $8(80 \%)$ & $10(100 \%)$ & \\
\hline \multirow[t]{2}{*}{ There is rat droppings } & Yes & $7(63,7 \%)$ & $4(36,3 \%)$ & $11(100 \%)$ & \multirow[t]{2}{*}{0,116} \\
\hline & No & $4(28,6 \%)$ & $10(71,4 \%)$ & $14(100 \%)$ & \\
\hline \multirow[t]{2}{*}{ There is a dead mouse } & Yes & $1(33,3 \%)$ & $2(66,7 \%)$ & $3(100 \%)$ & \multirow[t]{2}{*}{1,000} \\
\hline & No & $10(45,5 \%)$ & $12(54,5 \%)$ & $22(100 \%)$ & \\
\hline \multirow[t]{2}{*}{ The smell of rat urine } & Yes & $7(70 \%)$ & $3(30 \%)$ & $10(100 \%)$ & \multirow[t]{2}{*}{0,049} \\
\hline & No & $4(26,7 \%)$ & $11(73,3 \%)$ & $15(100 \%)$ & \\
\hline \multirow[t]{2}{*}{ pH Stagnant water } & Optimum & $11(73,3 \%)$ & $4(26,7 \%)$ & $15(100 \%)$ & \multirow[t]{2}{*}{0,001} \\
\hline & Not Optimum & 0 & $10(100 \%)$ & $10(100 \%)$ & \\
\hline
\end{tabular}


The relationship of environmental conditions that affect the presence of Leptospira bacteria in rats that were statistically tested using the Fisher exact test showed that the relationship of the presence of sewers with stagnant water with the presence of Leptospira bacteria in rats with a $\mathrm{p}$-value $=0,000<0.05$ which means the test results are meaningful, the relationship of the existence of standing water other than sewers with the presence of Leptospira bacteria in rats with a pvalue $=0.026<0.05$ which means the test results are significant.

The relationship between the presence of waste in the gutters with the presence of Leptospira bacteria in rats with a p-value $=0.005<0.05$, which means the test results are significant, the relationship between the presence of waste in the gutter with the presence of Leptospira bacteria in rats with a p-value $=0.007<$ 0.05, which means the results Significant test, the relationship of food availability that is affordable by rats with the presence of Leptospira bacteria in rats with a $\mathrm{p}$-value $=1,000>0.05$, which means the test results are not significant, the relationship of waste storage conditions with the presence of Leptospira bacteria in rats with a p-value $=0.099>0.05$ which means the test results are not significant, the relationship of rat droppings with the presence of Leptospira bacteria in mice with a $\mathrm{p}$-value $=0.116>0.05$ which means the test results are not significant.

The relationship of rat carcasses with the presence of Leptospira bacteria in rats with a p-value = $1,000>0.05$ which means the test results were not significant, the relationship of rat urine odor with the presence of Leptospira bacteria in rats with a p-value = $0.049<0.05$ which means the test results were significant, and the relationship of stagnant water $\mathrm{pH}$ with the presence of Leptospira bacteria in rats with a pvalue $=0.001<0.05$, which means that the test results are significant, there are six environmental conditions variables in the presence of rats that are significant with the presence of Leptospira bacteria in rats while four environmental conditions variables of rats are not significant with the presence of Leptospira bacteria in rat.

\section{DISCUSSION}

This study showed that the rats caught in the flood-prone areas of Makassar City were most found were 18 male rats $(72 \%)$ and 10 positive Leptospira $(40 \%)$. Whereas female sex rats were found as many as 7 tails (28\%) and positive Leptospira only 1 tail (4\%). Rats that are caught according to the location of traps in Makassar City's flood-prone areas are sewer rat (Rattus norvegicus), house rat (Rattus tanezumi), and house mice (Mus musculus), which include; Rattus norvegicus was caught outside of the house by $9(60 \%)$, in the house by $6(40 \%)$ and positively contained Leptospira bacteria by $8(53.3 \%)$ with $6(75 \%)$ each caught in outside and 2 tails $(25 \%)$ were caught inside the house,
Rattus tanezumi was caught outside the house by 6 tails $(66.7 \%)$, inside the house by 3 tails $(33.3 \%)$ and positive Leptospira by 2 tails $(22,2 \%)$ were caught in the house while Mus musculus was $1(100 \%)$ and positive was captured in the house.

Research conducted by Saragih [13] concerning the type and density of mice in the orphanage of Semarang City. The results showed that the types of mice that were caught were Rattus norvegicus by $25 \%$, and Mus musculus $37.5 \%$. However, it differs from research conducted by Manyullei [14] regarding the identification of rat and ectoparasite densities in the seaport region of Manokwari, Papua Province. The results showed that the mice that were caught were, Rattus tanezumi by $52.17 \%$, Rattus norvegicus by $43.47 \%$, and Cecurut by $4.34 \%$. Research on the analysis of environmental characteristics in the incidence of leptospirosis in Demak Regency, found Rattus norvegicus, Ratttus tanezumi, Bandicota indica and Rattus exulans rats. This shows that the types of mice that were caught followed the characteristics of the location of catching rats $\left[15^{]}\right.$.

Catching rats carried out in flood-prone areas in Makassar City was obtained as many as 25 animals during 4 days of trapping. The number of mice that are caught is as much as 5-7 tails per day using 100 live traps (single live trap) which only has one side of the entrance. The working principle of this trap is that the trap door will be closed when the bait is pulled by the rat, and the rat will be trapped. The bait used during the installation of mouse traps is roasted coconut. Every day the traps are controlled so that the bait can be replaced if it seems improper to use.

The type of positive mice that contained Leptospira bacteria were Rattus norvegicus, Rattus tanezumi, and Mus musculus. However, Rattus norvegicus was $8(53.3 \%)$, Rattus tanezumi was 2 (22.2\%), and Mus musculus was only 1 (100\%). This shows that Mus musculus is more dominant containing Leptospira bacteria compared to Rattus tanezumi and Rattus norvegicus. Male and adult mice are more at risk of being infected with Leptospira bacteria because the movement patterns of these mice are greater than that of female and young mice $\left[16^{]}\right.$.

Research conducted by Da Silva [17] regarding the characterization of Mus musculus, a pathogenic strain derived from Leptospira borgpetersenii. The results showed that six rats were captured alive in a trap set near a residence in the suburbs of Pelotas City, Brazil and found four serogroup strains of Leptospira borgpetersenii Ballum from Mus musculus. While research that is not in line is the study of rat identification and the presence of Leptospira bacteria in the flood area of Tempe Public Health Center, Wajo Regency, with the results of Rattus 
tanezumi, Rattus norvegicus, and Rattus tiomanicus containing negative Leptospira bacteria [18].

The relationship of environmental conditions that affect the presence of rats with the results of Leptospira bacteria in mice. There are several variables of environmental conditions related to the results of Leptospira bacteria examination in mice in accordance with the results of statistical tests using the fisher exact test, namely; the presence of sewers with stagnant water $(0,000)$, the presence of standing water other than sewers (0.026), the presence of sewage waste $(0.005)$, the presence of waste other than ditches $(0.007)$, and the smell of rat urine (0.049). Environmental risk factors that have been proven to be related to the incidence of leptospirosis are the presence of standing water around the house such as sewers. The role of the presence of standing water around the house as a pathway for leptospirosis transmission occurs when the pool of water is contaminated by urine of mice or pets infected with Leptospira bacteria [19] Research conducted by Dewi \& Yudhastuti [20] regarding risk factors for leptospirosis in Gresik Regency. Obtained statistical test results with a p-value of 0.001 . The results show that there is a relationship between the presence of standing water and the incidence of leptospirosis in Gresik Regency.

Research conducted by Maniiah [21] regarding the incidence of leptospirosis in Semarang City. Obtained that the p-value of 0.014 which means that there is a significant relationship between the condition of the gutter with the incidence of leptospirosis with an odds ratio of 4.875 . The environmental conditions of leptospirosis sufferers in the working area of the Pengandan Public Health Center show the condition of clogged gutters, lots of garbage and makes a lot of stagnant water or water flow not smooth. If the water flow is smooth, the risk of flooding decreases. In addition, if there is rubbish in the gutter, it can clog the gutter and make the stagnant gutter also invite rats [22].

Sewers are a place that is often used as a place to live mice or paths into the house. This is because the condition of wastewater discharges from inside the house generally there are channels that are connected with sewers in the home environment. Rats usually urinate in a pool of water in a ditch, so that through a pool of water will cause the bacteria Leptospira enter the human body. Especially if the sewer flow stops, is not smooth, flooded, and overflows when it rains so it is easy for rats to pass [23].

During the rainy season, people are often in contact with environments contaminated by floods that carry waste water to the streets and settlements. Slum dwellers are more vulnerable to exposure to pathogenic leptospires. Most clinical cases occur during the rainy season due to lack of drainage systems in slums [24]. The presence of rats is also caused by the presence of garbage in the house that is not managed properly and the lighting is not bright enough, would be preferred by rats. The open waste condition has a risk of 16.3 times greater in the spread of leptospirosis. The presence of rubbish, especially food scraps thrown in a place of garbage that does not meet the requirements, will invite mice. Piles of garbage around the house will become a nest and a place to find food for mice $\left[25^{]}\right.$. Factors causing leptospirosis are the presence of signs of the presence of rats that can spread the Leptospira bacteria into the environment, one of the signs is in rat droppings, rat urine, rat carcasses, and mice that roam [26].

\section{CONCLUSIONS}

The types of rats that are caught in flood prone areas of Paccerakkang, Makassar City are Mus musculus, Rattus norvegicus, and Rattus tanezumi. The success of catching (Success Trap) of rats in Makassar City's flood prone areas is $25 \%$. It was found that $44 \%$ of rat that were positive contained Leptospira bacteria, namely Mus musculus, Rattus norvegicus, and Rattus tanezumi. Environmental conditions that affect the presence of rat in flood-prone areas in Paccerakkang, Makassar City, are gutters with stagnant water, standing water other than gutters, sewage in sewage, and rubbish in addition to sewage, rat urine, and optimum $\mathrm{pH}$ of stagnant water. We recommend to the Paccerakkang inhabitants who reside in flood-prone areas, to always maintain environmental conditions such as cleaning the environment suspected of being a habitat for rats. To the next researcher, it is better to do the MAT test in order to see the comparison of the level of accuracy and sensitivity of the PCR test that has been done.

\section{REFERENCES}

1. Omudu, E. A., \& Ati, T. T. (2010). A survey of rats trapped in residential apartments and their ectoparasites in Makurdi, Nigeria. Research Journal of Agriculture and Biological Sciences, 6(2), 144149.

2. Rahdar, M., Vazirianzadeh, B., Rointan, E. S., \& Amraei, K. (2015). Identification of collected ectoparasites of rodents in the west of Khuzestan Province (Ahvaz and Hovizeh), southwest of Iran. Asian Pacific Journal of Tropical Disease, 5(8), 627-631.

3. Wang, C., \& He, H. (2013). Leptospira spp. in commensal rodents, Beijing, China. Journal of Wildlife Diseases, 49(2), 461-463.

4. Benacer, D., Thong, K. L., Verasahib, K. B., Galloway, R. L., Hartskeerl, R. A., Lewis, J. W., \& Mohd Zain, S. N. (2016). Human leptospirosis in Malaysia: reviewing the challenges after 8 decades (1925-2012). Asia Pacific Journal of Public Health, 28(4), 290-302.

5. Desvars, A., Naze, F., Vourc'h, G., Cardinale, E., Picardeau, M., Michault, A., \& Bourhy, P. (2012). Similarities in Leptospira serogroup and species distribution in animals and humans in the Indian 
ocean island of Mayotte. The American journal of tropical medicine and hygiene, 87(1), 134-140.

6. Loan, H. K., Van Cuong, N., Takhampunya, R., Kiet, B. T., Campbell, J., Them, L. N., ... \& Hien, V. B. (2015). How important are rats as vectors of leptospirosis in the Mekong Delta of Vietnam?. Vector-Borne and Zoonotic Diseases, 15(1), 56-64.

7. Costa, F., Hagan, J. E., Calcagno, J., Kane, M., Torgerson, P., Martinez-Silveira, M. S., ... \& Ko, A. I. (2015). Global morbidity and mortality of leptospirosis: a systematic review. Plos negl trop dis, 9(9), e0003898.

8. Kementerian Kesehatan Republik Indonesia. (2018). Profil Kesehatan Indonesia. Available from:

https://pusdatin.kemkes.go.id/folder/view/01/struct ure-publikasi-data-pusat-data-dan-informasi.html

9. Syamsuar, A. D., Maria, I. L., \& Hatta, M. (2018). Environmental Health Risk Assessment in Flood Prone Area; Case Study in Wajo District, 9-16.

10. Sholichah, Z., \& Rahmawati, R. (2017). Sebaran Infeksi Leptospira Patogenik pada Tikus dan Cecurut di Daerah Pasca Banjir Kabupaten Pati dan Endemis Boyolali. Balaba: Jurnal Litbang Pengendalian Penyakit Bersumber Binatang Banjarnegara, 173-182.

11. Sumanta, H., Wibawa, T., Hadisusanto, S., Nuryati, A., \& Kusnanto, H. (2015). Spatial analysis of Leptospira in rats, water and soil in Bantul District Yogyakarta Indonesia. Open Journal of Epidemiology, 5(01), 22.

12. Fajriyah, S. N, Udiyono, A., Saraswati, L. D. (2017). Environmental and Risk Factors of Leptospirosis: A Spatial Analysis in Semarang City Environmental and Risk Factors of Leptospirosis: A Spatial Analysis in Semarang City. 2017. Improving the Competitiveness of UPI as a Research-Based Teaching Improving the Competitiveness of UPI as a Research-Based Teaching University.

13. Saragih, R. K. P., Martini, M., \& Tarwatjo, U. (2019). Jenis dan Kepadatan Tikus Di Panti Asuhan "X" Kota Semarang. Jurnal Kesehatan Masyarakat (e-Journal), 7(1), 260-270.

14. Manyullei, S., Natsir, M. F., \& Batkunda, A. (2020). Identification of Rat Density and Ectoparasites in Seaport Area of Manokwari, Papua Province. Open Access Macedonian Journal of Medical Sciences, 8(E), 204-208.

15. Ikawati, B., Sulistiyani, S., \& Nurjazuli, N. (2009). Analisis Karakteristik Lingkungan Pada Kejadian Leptospirosis di Kabupaten Demak Jawa Tengah Tahun 2009. Jurnal Kesehatan Lingkungan Indonesia, 8(2), 39-46.

16. Simões, R. O., Júnior, A. M., Olifiers, N., Garcia,
J. S., Bertolino, A. V. F., \& Luque, J. L. (2014). A longitudinal study of Angiostrongylus cantonensis in an urban population of Rattus norvegicus in Brazil: the influences of seasonality and host features on the pattern of infection. Parasites \& Vectors, 7(1), 100.

17. da Silva, É. F., Félix, S. R., Cerqueira, G. M., Fagundes, M. Q., Neto, A. C., Grassmann, A. A., \& Dellagostin, O. A. (2010). Preliminary Characterization of Mus musculus-Derived Pathogenic Strains of Leptospira borgpetersenii Serogroup Ballum in a Hamster Model. The American journal of tropical medicine and hygiene, 83(2), 336-337.

18. Syamsuar., Amqam, H., Daud, A. (2018). Study on Identification of Rats and the Existence of Leptospira Bacteria. sp in the Flood Area of Puskesmas Tempe, Wajo District, 7(3).

19. Riyaningsih, R., \& Hadisaputro, S. (2012). Faktor Risiko Lingkungan Kejadian Leptospirosis di Jawa Tengah (Studi Kasus di Kota Semarang, Kabupaten Demak dan Pati). Jurnal Kesehatan Lingkungan Indonesia, 11(1), 87-94.

20. Dewi, H. C., \& Yudhastuti, R. (2019). Faktor Risiko Kejadian Leptospirosis Di Wilayah Kabupaten Gresik (Tahun 2017-2018). Jurnal Keperawatan Muhammadiyah, 4(1).

21. Maniiah, G., Raharjo, M., \& Dewanti, N. A. Y. (2016). Faktor Lingkungan yang Berhubungan dengan Kejadian Leptospirosis di Kota Semarang. Jurnal Kesehatan Masyarakat (e-Journal), 4(3), 792-799.

22. Prihantoro, T., \& Siwiendrayanti, A. (2017). Karakteristik dan Kondisi Lingkungan Rumah Penderita Leptospirosis Di Wilayah Kerja Puskesmas Pegandan Kota Semarang. JHE (Journal of Health Education), 2(2), 178-184.

23. Pertiwi, S. M. B., Setiani, O., \& Nurjazuli, N. (2014). Faktor Lingkungan Yang Berkaitan Dengan Kejadian Leptospirosis di Kabupaten Pati Jawa Tengah. Jurnal Kesehatan Lingkungan Indonesia, 13(2), 51-57.

24. Ullmann, L. S., \& Langoni, H. (2011). Interactions between environment, wild animals and human leptospirosis. Journal of Venomous Animals and Toxins including Tropical Diseases, 17(2), 119129.

25. Nugroho, A. (2015). Analisis faktor lingkungan dalam kejadian leptospirosis di Kabupaten Tulungagung. BALABA: Jurnal Litbang Pengendalian Penyakit Bersumber Binatang Banjarnegara, 73-80.

26. Nurhandoko, F., \& Siwiendrayanti, A. (2018). Zona Kerentanan Kejadian Leptospirosis Ditinjau dari Sisi Lingkungan. HIGEIA (Journal of Public Health Research and Development), 2(3), 498-509. 